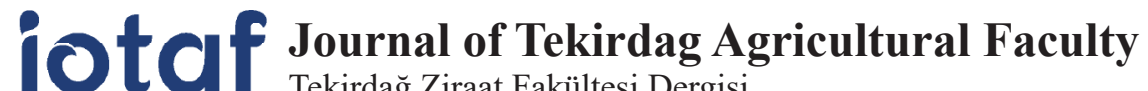 \\ Tekirdağ Ziraat Fakültesi Dergisi
}

\section{Farklı Sıcaklık ve Tuz Konsantrasyonlarının Bazı Silajlık Mısır Çeşitlerinin Çimlenme Özellikleri Üzerine Etkileri}

\author{
Effects of Different Temperatures and Salt Concentrations on the Germination Of Some Corn \\ Silage Varieties
}

\section{Sadık ÇAKMAKÇI ${ }^{1 *}$, Aynur DALLAR ${ }^{*}$}

\section{$\ddot{O} \mathbf{z}$}

Bu çalışma ile Akdeniz sahil koşullarında yetiştirilen 3 silajlık mısır çeşidinin farklı sıcaklık ve tuz konsantrasyonlarında çimlenme döneminde gösterdikleri tepkileri belirlenmiştir. Deneme en uygun çeşit, çimlenme sıcaklı̆̆ saptamak amacıyla çimlendirme dolabında Petri kapları içerisinde planlanmıştır. Araştırma materyali olarak kullanılan silajlık mısır çeşitleri (Batem Efe, Gözdem ve Burak) Batı Akdeniz Tarımsal Araştırma Merkezi (BATEM) tarafından karşılanmıştır. Bu çeşitlere 3 farklı sıcaklık $\left(24{ }^{\circ} \mathrm{C}, 28{ }^{\circ} \mathrm{C}, 32{ }^{\circ} \mathrm{C}\right)$ değeri, sabit \% $75^{\prime}$ lik nem oranında, 9 farklı tuz dozu (saf su, 1500 , 3000, 5000, 7500, 10000, 15000, 20000, 25000 ppm tuz) uygulanmıştır. Araştırma bölünen bölünmüş parseller deneme deseninde 3 tekrarlamalı olarak kurulmuştur. Mısır çeşitlerinin bu koşullardaki çimlenme oranları, yaş sap ağırlıkları, yaş kök ağırlıkları, kuru sap ağırlıkları ve kuru kök ağırlıkları incelenmiştir. Varyans analizi sonucunda çimlenme oranında; sıcaklık, çeşit, sıcaklık*çeşit, tuz konsantrasyonu, sıcaklık*tuz konsantrasyonu, çeşit*tuz konsantrasyonu ve sıcaklık*çeşit*tuz konsantrasyonu üçlü interaksiyonu önemli bulunmuştur. Yaş sürgün ağırlığı özelliğinde; sıcaklık, çeşit ve tuz konsantrasyonu önemli olmuştur. Bunun yanında yaş kök ağırlığında; sıcaklık, çeşit ve tuz konsantrasyonunun önemli olduğu belirlenmiştir. Çimlenme özelliklerine bak1lırken 20000 ppm ve 25000 ppm'lik konsantrasyonlarda çimlenme görülmemesi üzerine bu iki konsantrasyon istatistiki analize alınmamıştır. Aynı zamanda sürgün kuru ve kök kuru ağırlıkları ortalamaları istatistiki açıdan önemli bulunmamıştır. Ortalamalara uygulanan LSD testi sonuçları toplu olarak değerlendirildiğinde çeşitler içerisinde Gözdem ön plana çıkmaktadır. Tüm çeşitlerde $24{ }^{\circ} \mathrm{C}$ ve saf su koşullarında en yüksek değerler sağlanmıştır. Denemede kullanılan çeşitlerin 5000 ppm'lik tuz konsantrasyonuna kadar fide gelişimlerini tamamladıkları görülmüştür.

Anahtar Kelimeler: Çimlenme gücü, fide gelişimi, mısır silajı, sıcaklık, tuz konsantrasyonu.

\begin{abstract}
The present study determines the reaction of 3 maize silage varieties cultivated under the Mediterranean coastal conditions and at different temperatures and salt concentrations during germination period. The experiment has been planned in Petri dishes in a germination chamber with the intent of detecting the optimum variety, germination temperature and salt concentration. Maize silage varieties (Batem Efe, Gözdem and Burak) used as the research material were supplied by Batı Akdeniz Agricultural Research Institute (BATEM). Three different temperatures $\left(24^{\circ} \mathrm{C}, 28{ }^{\circ} \mathrm{C}, 32^{\circ} \mathrm{C}\right)$ and 9 different salt dosages (distilled water, $1500,3000,5000,7500,10000,15000,20000,25000$ ppm salt) with fixed $75 \%$ humidity rate have been applied to these varieties. The research has been set in split-split plot design with 3 replications. Maize varieties' germi- nation rate, damp stalk weight, damp root weight, dry stalk weight and dry root weight in these conditions were analyzed. As a result of the variance analysis; temperature, variety, temperature*variety, salt concentration, temperature*salt concentration, variety*salt concentration and temperature*variety*salt concentration triple interaction in germination rate have been deemed significant. In stalk weight characteristic; temperature, variety and salt concentration have been influential. Additionally, it has been determined that in root weight temperature, variety and salt concentration play a significant role. Given that no germination has been observed with 20000 and 25000 ppm concentrations whilst germination characteristics were tested, these two consent- rations were not included in the statistical analysis. Furthermore, dry stalk and dry root weight averages were not found important statistically. The Gözdem variety comes into prominence amongst the varieties when the results of LSD test, practiced on the averages, were evaluated collectively. In all varieties, the highest rates were obtained in $24{ }^{\circ} \mathrm{C}$ and distilled water conditions. It has been observed that the varieties used in this study have completed their seedling development up to $5000 \mathrm{ppm}$ salt concentration.
\end{abstract}

Keywords: Germination vigor, maize silage, salt concentrations, seedling development, temperature

\footnotetext{
1*Sorumlu Yazar/Corresponding Author: Sadık Çakmakçı, Akdeniz Üniversitesi, Ziraat Fakültesi, Tarla Bitkileri Bölümü, Antalya, Türkiye. E-mail: cakmakci@akdeniz.edu.tr

${ }^{1}$ Aynur Dallar, Akdeniz Üniversitesi, Ziraat Fakültesi, Tarla Bitkileri Bölümü, Antalya, Türkiye.

Atıf/Citation: Çakmakçı, S., Dallar, A. Farklı sıcaklık ve tuz konsantrasyonlarının bazı silajlık mısır çeşitlerinin çimlenme özellikleri üzerine etkileri. Tekirdă̆ Ziraat Fakültesi Dergisi, 16(2), 121-132.
} 
Dünya'da en fazla üretilen (1 milyar ton) tahıl olan mısırın birim alan verimi buğday ve arpanın iki katıdır. Türkiye'de yıllık ortalama 660 bin hektarlık alanda 5,9 milyon ton mısır üretilmektedir (FAO 2016).

Mısır bitkisinin anavatanı Orta Amerika'da Meksika-Guatemala olup, binlerce yıldır bölgenin ana ürünü olarak yetiştirilmektedir. Kıtada henüz insan yokken mısırın var olduğu arkeolojik kazılar sonucunda anlaşılmıştır. 15.yy içinde buradan Kuzey Afrika yoluyla Asya'ya ve daha sonra Hindistan ve Çin gibi Uzakdoğu ülkelerine götürülmüştür. Mısır yolu ile ülkemize girmiş ve hala uygun ekolojik koşullar altında en yüksek ürünü sağlayan bir bitki konumuna gelmiştir. Meksika ve Kolombiya'da yaygın olarak bulunur. Meksika'da 7000 yıldır yetiştirildiği bilinmektedir. Tropik bir bitki olmasına rağmen üzerinde yapılan yoğun 1slah çalışmaları ile Dünya üzerinde Ekvator'dan Baltık Denizi'ne kadar $\left(60^{\circ}\right.$ kuzey enlemi ile $42^{\circ}$ güney enlemi arasında denizden $4000 \mathrm{~m}$ yüksekliğe kadar) geniş bir alana yayılmıştır (Gençkan, 1983).

Silaj üretiminde birçok bitki kullanılabilirse de mısır, sorgum ve yonca bu amaçla en çok kullanılan bitkilerdir. Özellikle Kuzey Amerika ve Güney Avrupa'da mısır en önemli silaj bitkisi durumundadır. Ülkemizde silaj üretiminde mısır bitkisi ilk sırayı almaktadır. Silaj için uygun biçim devrelerinde kuru madde ve şeker oranının yüksekliği, kolayca fermente olması nedenleri ile mısır mükemmel bir silaj bitkisi kabul edilir (Açıkgöz, 2001). Mısır bitkisi son 30 yıl içerisinde silaj yemi üretimi için geniş alanlara yayılarak ekimi yapılan bir üründür. Silajın besleme değerinin ve lezzetinin yüksekliği gibi nedenlerle, dünyadaki en önemli silaj bitkilerinden birisi durumuna gelmiştir (Sarıcan ve Çete, 1998).

Bitkiler yaşamları boyunca çeşitli stres koşullarına maruz kalırlar. Bitkilerin gelişimi, metabolizması ve verimliliği stres koşullarından şiddetli etkilenir. Bitkisel verimi sınırlandıran başlıca abiyotik stres faktörleri; kuraklık, besin maddesi eksikliği ya da toksisitesi, tuzluluk, aşırı sıcaklık, karasal ve atmosferik kirlilik ve radyasyondur (Lawlor, 2000). Akdeniz havzasının yarı kurak bölgelerinde, tuzluluk stresi artmakta ve bitkilerin gelişimini kısıtlayan birincil sınırlayıcı çevre koşulu haline gelmektedir (Patanè ve ark. 2013).

Tuzluluk, bitkiler üzerindeki doğrudan etkisini osmotik ve iyon stresi oluşturarak gösterirken, dolaylı etkisini (sekonder etki) bu stres faktörleri sonucu bitkide meydana gelen yapısal bozulmalar ve toksik bileşiklerin sentezlenmesi ile göstermektedir. NaCl'nin sebep olduğu başlıca sekonder etkileri; DNA, protein, klorofil ve zar fonksiyonuna zarar veren AOT sentezi; fotosentezin inhibisyonu; metaboliktoksisite; K+ alımının engellenmesi ve hücre ölümü olarak sayılabilir (Botella ve ark. 2005; Hong ve ark. 2009). Tuz stresinin bitkiler üzerindeki etkileri; bitkinin çeşidine, uygulanan tuz çeşidi ile miktarına ve maruz kalma süresine bağlı olarak değiş̧mektedir. Tuzlu ortamlarda bitkiler genotipik farklılıklara bağlı olarak çok farklı cevaplar verirler (Dajic, 2006). Tuzluluğa karşı verilen bu farklı büyüme cevapları sadece iki bitki türü için değil aynı türün farklı çeşitleri için de geçerlidir (Munns, 2002).

$\mathrm{Bu}$ sebepler sonucunda ele alınan bu çalışma içerisinde tuzluluk stresine dayanıklı, çimlenme gücü yüksek ve fide gelişimi dayanıklılığa en ideal olan çeşitler deneme faktörleri ve analizler sonucunda değerlendirilerek karşılaştırmaları yapılmıştır. Böylece Akdeniz sahil kuşağında tuzlu stres koşullarına dayanıklı çeşitleri analizlerle belirleyerek üreticiye en uygun ve getirisi yüksek çeşitler ile silajlık mısır üretiminin karlılı̆̆ının artırılması öngörülmektedir.

$\mathrm{Bu}$ çalışma, Akdeniz sahil kuşağında, sulama suyu ve topraklarının tuz içermesi ve bu durumun mısır tarımını olumsuz etkilemesinin sonucu planlanmıştır. Bu nedenle öncelikli amaç tuzlu koşullarda dayanıklı olan çeşidi belirlemektir. Ayrıca tuz stresinin tarımsal özellikler üzerine etkisi saptanarak bu yönde üreticinin bilgilendirilmesi, daha kaliteli ve verimli üretim yapılmasının sağlanması ve böylece ekonomik açıdan da üreticiye yarar sağlaması amaçlanmaktadır.

\section{Materyal ve Yöntem}

Bu çalışmada Akdeniz Sahil Kuşağında yetiştirilen silajlık mısır çeşitlerinin sıcaklık ve tuzluluğa dayanımları incelenmiştir. Deneme 3 faktörlü olup, tesadüf parsellerinde bölünen bölünmüş parseller deneme desenine göre kurulmuştur. Çalışmada, 3 farklı sıcaklık, 3 farklı silajlık mısır çeşidi, 9 farklı tuz konsantrasyonu kullanılmış ve 3 tekrarlamalı olarak yürütülmüştür. Ana parsellere sıcaklık, alt parsellere çeşit ve altın altı parsellere de tuz dozları yerleştirilmiştir. Bu uygulamalar çizelge 1.'de verilmişsir. 
Çizelge 1. Denemede ele alınan uygulamalar.

Table 1. Practicesdealtwith in theexperiment.

\begin{tabular}{ccc}
\hline Sicaklıklar $\left({ }^{\circ} \mathrm{C}\right)$ & Çeşitler & T.K. $(\mathrm{ppm})$ \\
\hline 24 & Batem Efe & Saf su \\
\hline 28 & Gözdem & 1500 \\
\hline 32 & Burak & 3000 \\
\hline & & 5000 \\
\hline & & 7500 \\
\hline & 10000 \\
\hline & & 15000 \\
\hline & 20000 \\
\hline
\end{tabular}

Çalışma, laboratuarda steril ve kontrollü koşullarda petri kaplarında kurulmuştur. Bu amaçla kurutma kağıdı yerleştirilen petri kaplarına çalışmada kullanılan üç çeşitten 10'ar adet tohum konulmuştur. Petri kaplarına konulan tohumlar tesadüfi olarak seçilmiş ve ağılıkları tartılmıştır. Çalışmada kullanılacak tuz konsantrasyonlarını hazırlamak amacıyla çizelge 2.'de verilen miktarlarda tuz tartılmış ve saf su içinde ç̧̈zdürülmüştür. Bu çözeltiden seyreltme yaparak 9 farklı tuz konsantrasyonu erlen kaplarında hazırlanmış ve EC değerleri ölçülmüştür.

Çizelge 2. Tuz konsantrasyonları için solüsyonların hazırlanış miktarları.

Table 2. Amounts of preparation of solutionsfor salt concentrations.

\begin{tabular}{ccc}
\hline Uygulama & Saf su & $100 \mathrm{ml}$ \\
\hline Uygulama & $1500 \mathrm{ppm}: 150 \mathrm{mg}=0,15 \mathrm{gr} \mathrm{NaCl}$ & $0,15 \mathrm{gr} \mathrm{NaCl}+99,85 \mathrm{ml} \mathrm{su}$ \\
\hline Uygulama & $3000 \mathrm{ppm}: 300 \mathrm{mg}=0,30 \mathrm{gr} \mathrm{NaCl}$ & $0,30 \mathrm{gr} \mathrm{NaCl}+99,7 \mathrm{ml} \mathrm{su}$ \\
\hline Uygulama & $5000 \mathrm{ppm}: 500 \mathrm{mg}=0,50 \mathrm{gr} \mathrm{NaCl}$ & $0,50 \mathrm{gr} \mathrm{NaCl}+99,5 \mathrm{ml} \mathrm{su}$ \\
\hline Uygulama & $7500 \mathrm{ppm}: 750 \mathrm{mg}=0,75 \mathrm{gr} \mathrm{NaCl}$ & $0,75 \mathrm{gr} \mathrm{NaCl}+99,25 \mathrm{ml} \mathrm{su}$ \\
\hline Uygulama & $10000 \mathrm{ppm}: 1000 \mathrm{mg}=1 \mathrm{gr} \mathrm{NaCl}$ & $1 \mathrm{gr} \mathrm{NaCl}+99,0 \mathrm{ml} \mathrm{su}$ \\
\hline Uygulama & $15000 \mathrm{ppm}: 1500 \mathrm{mg}=1,5 \mathrm{gr} \mathrm{NaCl}$ & $1,5 \mathrm{gr} \mathrm{NaCl}+98,5 \mathrm{ml} \mathrm{su}$ \\
\hline Uygulama & $20000 \mathrm{ppm}: 2000 \mathrm{mg}=2 \mathrm{gr} \mathrm{NaCl}$ & $2 \mathrm{gr} \mathrm{NaCl}+98,0 \mathrm{ml} \mathrm{su}$ \\
\hline Uygulama & $25000 \mathrm{ppm}: 2500 \mathrm{mg}=2,5 \mathrm{gr} \mathrm{NaCl}$ & $2,5 \mathrm{gr} \mathrm{NaCl}+97,5 \mathrm{ml} \mathrm{su}$
\end{tabular}

Çizelge 3'te görüldüğü üzere tuz çözeltileri her sıcaklık denemesi için ayrı ayrı hazırlanmış ve her birinin EC değeriölçülmüştür. Hazırlanan bu solüsyonlardan petri kaplarına eklenerek çimlenme başlatılmıştır. Her petri kabına ağırlıkları tartılan 10 tohumun \%150'si oranında solüsyon ayarlanabilir pipet ile eklenmiştir (Kaçar, 1989).

Çizelge 3. Farklı tuz konsantrasyonları için hazırlanan solüsyonların EC değerleri ve ölçüm esnasındaki sıcaklık dereceleri.

Table 3. The EC values of the solutions prepared for different salt concentrations and the temperature gradients during the measurement.

\begin{tabular}{ccccccc}
\hline Tuz Konsantr. & \multicolumn{2}{c}{$24{ }^{\circ} \mathrm{C}$ sıcaklık için } & \multicolumn{2}{c}{$28{ }^{\circ} \mathrm{C}$ sıcaklık için } & \multicolumn{2}{c}{$32{ }^{\circ} \mathrm{C}$ sıcaklık için } \\
\hline & EC değeri & ${ }^{\circ} \mathrm{C}$ & EC değeri & ${ }^{\circ} \mathrm{C}$ & $\mathrm{C}$ değeri & ${ }^{\circ} \mathrm{C}$ \\
\hline 1.Uygulama & $0,0015 \mathrm{mS} / \mathrm{cm}$ & 28.2 & $0,0153 \mathrm{mS} / \mathrm{cm}$ & 23.3 & $0,0512 \mathrm{mS} / \mathrm{cm}$ & 25,0 \\
\hline 2.Uygulama & $3,10 \mathrm{mS} / \mathrm{cm}$ & 28.5 & $2,85 \mathrm{mS} / \mathrm{cm}$ & 23.8 & $2,89 \mathrm{mS} / \mathrm{cm}$ & 25,1 \\
\hline 3.Uygulama & $4,88 \mathrm{mS} / \mathrm{cm}$ & 28.3 & $5,41 \mathrm{mS} / \mathrm{cm}$ & 22.8 & $5,47 \mathrm{mS} / \mathrm{cm}$ & 25,0 \\
\hline 4.Uygulama & $8,68 \mathrm{mS} / \mathrm{cm}$ & 28.3 & $8,83 \mathrm{mS} / \mathrm{cm}$ & 23.2 & $8,33 \mathrm{mS} / \mathrm{cm}$ & 25,0 \\
\hline
\end{tabular}




\begin{tabular}{ccccccc}
\hline (Çizelge 2. devam) & \multicolumn{7}{c}{} \\
\hline 5.Uygulama & $11,46 \mathrm{mS} / \mathrm{cm}$ & 28.4 & $12,90 \mathrm{mS} / \mathrm{cm}$ & 23.4 & $12,12 \mathrm{mS} / \mathrm{cm}$ & 25,0 \\
\hline 6.Uygulama & $13,65 \mathrm{mS} / \mathrm{cm}$ & 28.4 & $16,60 \mathrm{mS} / \mathrm{cm}$ & 22.7 & $16,19 \mathrm{mS} / \mathrm{cm}$ & 25,0 \\
\hline 7.Uygulama & $22,9 \mathrm{mS} / \mathrm{cm}$ & 28.3 & $24,4 \mathrm{mS} / \mathrm{cm}$ & 23.0 & $19,62 \mathrm{mS} / \mathrm{cm}$ & 25,0 \\
\hline 8. Uygulama & $31,3 \mathrm{mS} / \mathrm{cm}$ & 28.2 & $32,8 \mathrm{mS} / \mathrm{cm}$ & 23.8 & $27,7 \mathrm{mS} / \mathrm{cm}$ & 24,8 \\
\hline 9.Uygulama & $37,1 \mathrm{mS} / \mathrm{cm}$ & 28.1 & $42,8 \mathrm{mS} / \mathrm{cm}$ & 23.6 & $35,7 \mathrm{mS} / \mathrm{cm}$ & 24,7
\end{tabular}

Solüsyonları eklenen petri kapları çimlendirme dolabına konulmuştur. Nem oranı sabit olarak \%75'e, sıcaklık değerleri ise çalışmanın gerektirdiği uygun değerlere ayarlanmıştır. Çimlendirme dolabına konulan petrilerden 4.gün gözlem ve ölçümleri alınmaya başlanmıştır. Gözlemler her petri kabındaki çimlenen tohum sayısı üzerinden değerlendirilmiştir. 4 gün boyunca gözlemleri alınan petri kapları içindeki tohumların son gün (7.gün; çimlenme oranı stabil hale geldiğinde) kökçük ve sapçık kısımları kesilmiştir.

Petri kabında çimlenen tohumların kökçükleri bir bistüri ile sürgün kısmı diğer bistüri ile kesilmiştir. Kökçükler ve sürgünler ayrı ayrı kese kağıtlarına, ağırlıkları alındıktan sonra konulmuştur.

Her bir tekrarlamadaki kökçük ve sürgün ağırlıkları tekrarlamalar birleştirilerek ve uygulamalar bakımından ortalama değerler verilerek yorumlanmıştır. Üç tekrarlamadan elde edilen kökçük ve sürgünler aynı kese kağıdında toplanarak, kurutma dolabına konulmuştur. Kurutma dolabında $70^{\circ} \mathrm{C}$ sıcaklıkta 24 saat bekletilen bitki materyalleri tartılarak ağırlıkları belirlenmiştir.

Çimlenme gözlemleri alınan tohumların, kesilen yaş kökçük ve yaş sürgün ağıllıklarının, kuru madde ağırlıklarının istatistiki analizleri Mstat programında tesadüf parsellerinde bölünen bölünmüş parseller deneme desenine uygulanarak hesaplanmıştır. Ortalamaların karşılaştırılması için LSD testi kullanılmıştır.

\section{Bulgular ve Tartışma}

Denemede ele alınan özelliklerden; çimlenme oranı, yaş sürgün ağırlığı ve yaş kök ağırlığı önemli çıkmıştır. Farklı tuz konsantrasyonu uygulamalarından 20000 ppm ve 25000 ppm (8 ve 9.) konsantrasyonlarında hiçbir çeşit ve sıcaklıkta çimlenme gözlenmediği için analizlere tabi tutulmamışlardır. Varyans analizi sonuçları çizelge 4.'te verilmiştir.

Çizelge 4. Birleştirilmiş varyans analiz tablosu.

Table 4. Consolidatedvarianceanalysistable.

\begin{tabular}{|c|c|c|c|}
\hline & Çimlenme Oranı $(\%)$ & Yaş Sürgün Ağırlığı (gr/bitki) & Yaş Kök Ağırlığı (gr/bitki) \\
\hline Varyasyon Kaynağı & F değeri & F değeri & F değeri \\
\hline Sicaklık & $54,13 * *$ & $37,45^{* *}$ & $8,98^{*}$ \\
\hline Ana Parsel Hatas1 & 1,03 & 0,91 & 0,84 \\
\hline Çeşit & $20,78^{* *}$ & $20,15^{* *}$ & $7,97 * *$ \\
\hline Sicaklık*Çeşit & $4,89 *$ & 0,38 & 3,15 \\
\hline Alt Parsel Hatası & 0,99 & 0,75 & 0,85 \\
\hline Tuz konsantrasyonu & $17,61^{* *}$ & $15,78^{* *}$ & $9,36 * *$ \\
\hline Sicaklık*Tuz konsantrasyonu & $2,54 * *$ & 1,71 & 0,49 \\
\hline Çeşit*Tuz konsantrasyonu & $1,98^{*}$ & 1,47 & 0,55 \\
\hline $\begin{array}{l}\text { Sicaklık*Çeşit* Tuz } \\
\text { konsantrasyonu }\end{array}$ & $1,74^{*}$ & 1,01 & 0,75 \\
\hline $\begin{array}{l}\text { Altın Altı Parsel Hatası } \\
0,05 \text { seviyesinde farkl1lığ } 1 \text { ifade }\end{array}$ & $\begin{array}{l}4,89^{* *} \\
\text { etmektedir. }\end{array}$ & $3,15^{* *}$ & $1,73 * *$ \\
\hline
\end{tabular}




\section{Çimlenme Oranı (\%)}

Çizelge 4.'te görüldüğü sıcaklık, çeşit, tuz konsantrasyonu ve sıcaklık*tuz konsantrasyonu interaksiyonu \%1 seviyesinde; sıcaklık*çeşit, çeşit* tuz konsantrasyonu ve sıcaklık*çeşit* tuz konsantrasyonu üçlü interaksiyonu ise $\% 5$ seviyesinde önemli bulunmuştur. Tüm varyasyon kaynaklarına ait LSD testi sonuçları ayrı ayrı çizelgeler halinde verilmiştir.

Çizelge 5. Sıcaklıkların çimlenme oranı üzerine etkisi.

Table 5. Effect of temperature on germination rate.

\begin{tabular}{ccrr}
\hline Sicaklıklar $\left({ }^{\circ} \mathrm{C}\right)$ & Ortalamalar & & \\
\hline 24 & 81,27 & $\mathrm{a}$ & \\
\hline 28 & 67,62 & $\mathrm{~b}$ & \\
\hline 32 & 45,87 & & $\mathrm{c}$ \\
\hline $\operatorname{LSD}(0,05): 8,40$ & & &
\end{tabular}

LSD testi sonuçlarına göre $24{ }^{\circ} \mathrm{C}$ en yüksek grupta yer alırken, $32{ }^{\circ} \mathrm{C}$ en düşük değeri vermiştir. $24{ }^{\circ} \mathrm{C} ; \% 81,27$ değeri ile en yüksek çimlenme değerini yakalamıştır. Mısır bir sıcak iklim bitkisi olmasına rağmen aşırı sıcaklık isteyen bir bitki değildir.

Hartmann ve ark. (1990) çimlenme süresini düzenleyen en önemli faktörlerden birisinin de sıcaklık olduğunu bildirmişlerdir. Dormansinin kontrolünde doğrudan ilişkilidir. Düşük sıcaklıklarda çimlenme oranı genellikle düşüktür. Ilıman iklimdeki bitkilerin tohumları optimum $24-30^{\circ} \mathrm{C}$ 'de çimlenirken; $4,5-40^{\circ} \mathrm{C}$ arasında geniş sıcaklık aralığında çimlenebilme yeteneğine sahiptirler. Ayrıca bu kuşaktaki bitkilerin tohumlarının çimlenebilmesi için tür ve çeşide göre değişen belli sürelerde düşük sıcaklığa $\left(3-4^{\circ} \mathrm{C}\right)$ tabi tutulmaları gerekmektedir.

Çizelge 6. Çeşitlerin çimlenme oranları üzerine etkileri.

Table 6. Effects of varieties on germinationrates.

\begin{tabular}{cccc}
\hline Çeşitler & Ortalamalar & & \\
\hline Gözdem & 73,17 & a & \\
\hline Batem Efe & 69,05 & a & \\
\hline Burak & 52,54 & & b \\
\hline LSD $(0,05): 7,38$ & & &
\end{tabular}

Çeşitler için yapılan LSD testi Gözdem çeşidini $(\% 73,17)$ öne çıkarırken; en düşük çimlenmeyi Burak çeşidi $(\% 52,54)$ vermiştir. Gözdem çeşidinin bin dane ağırlığı diğer iki çeşitten yüksektir. 1000 dane ağırlığı fazla olan tohumların endosperminde daha fazla besin maddesinin bulunduğu öne sürüldüğünden çimlenme oranını olumlu yönde etkileyebileceği düşünülebilir.

Avcı ve ark. (1987) bildirilerinde, beş farklı buğday çeşidinin ve değişik tohum iriliklerinin araştırıldığı bir denemede tohum iriliğinin bütün çeşitlerde verim artışı sağladığını ortaya koymuşlardır.

Çizelge 7. Tuz konsantrasyonları ortalamalarının çimlenme oranı üzerine etkisi.

Table 7. Effect of averages of salt concentrations on germination rate.

\begin{tabular}{cccc}
\hline T.K. $(\mathrm{ppm})$ & Ortalamalar & & \\
\hline Saf su & 77,78 & $\mathrm{a}$ & \\
\hline 3000 & 77,41 & $\mathrm{a}$ & \\
\hline 1500 & 77,04 & $\mathrm{a}$ & \\
\hline 5000 & 74,81 & $\mathrm{a}$ & \\
\hline 7500 & 54,44 & \multicolumn{2}{c}{$\mathrm{b}$} \\
\hline 10000 & 52,22 & \multicolumn{2}{c}{$\mathrm{b}$} \\
\hline 15000 & 40,74 & \multicolumn{2}{c}{$\mathrm{c}$} \\
\hline $\operatorname{LSD}(0,05): 10,28$ & & &
\end{tabular}

En yüksek çimlenme oranı sağlayan konsantrasyon, saf su $(\% 77,78)$ ve 3000 ppm $(\% 77,41)$ iken bunları 1500 ppm $(\% 77,04)$ takip etmiştir. En düşük çimlenme oranı ise 15000 ppm konsantrasyonundan $(\% 40,74)$ elde 
edilmiştir. Tuz konsantrasyonu arıı̧ gösterdikçe çimlenme oranı ortalamaları azalma göstermiştir.

Abiyotik bir tehlike olan tuzluluk, yüksek seviyelerde tohum çimlenmesini gerileterek (inhibe ederek) veya daha düşük seviyelerde dormansinin başlamasını teşvik ederek birçok olumsuz etkiye neden olur (De Villiers ve ark. 1994; Khan ve ark. 1997). Bu etkiler, düşük osmotik potansiyelden dolayı inhibasyonun azalması (Poljakoff-Mayber ve ark. 1994) toksisite nedeni ile enzimatik aktivitenin değişmesi (Gomes ve ark. 1988) protein metabolizmasının engellenmesi (Yupsanis ve ark. 1994) bitki büyüme regülatörlerinin dengesinin bozulması (Khan ve ark. 1994) tohumdaki besidokunun kullanımının azalması (Ahmad J. ve ark. 1992) ya da hücrelerin mitoz bölünmesinin engellenmesi (Bozcuk, 1991) ile gerçekleşmektedir.

\section{Yaş Sürgün Ağırlığı (gr/bitki)}

Çizelge 4.'te görüldüğü gibi varyans analiz sonucunda sıcaklık, çeşit ve tuz konsantrasyonu \%1 düzeyinde önemli bulunmuştur. Tüm varyasyon kaynaklarına ait LSD testi sonuçları ayrı ayrı çizelgeler halinde aşağıdaki gibi verilmiştir.

Çizelge 8. Sıcaklık ortalamalarının yaş sürgün ağırı̆̆ğı üzerine etkisi.

Table 8. Theeffect of temperatureaverages on wet-exileweight.

\begin{tabular}{|c|c|c|}
\hline Sicaklık $\left({ }^{\circ} \mathrm{C}\right)$ & Ortalamalar & \\
\hline 24 & 0,05 & $\mathrm{a}$ \\
\hline 28 & 0,02 & $\mathrm{~b}$ \\
\hline 32 & 0,02 & $\mathrm{~b}$ \\
\hline
\end{tabular}

Yaş sürgün ağırlığı için optimum sıcaklık değeri $24{ }^{\circ} \mathrm{C}$ olarak belirlenmiştir. En düşük değer ise $28^{\circ} \mathrm{C}$ ve 32 ${ }^{\circ} \mathrm{C}$ 'de elde edilmiştir.

Sava (1995) bildirisinde, sürgün ağırlığı için bazı yem bitkilerinin $20^{\circ} \mathrm{C}$ 'de optimum nokta olduğunu ileri sürmüştür.

Çizelge 9. Çeşit ortalamalarının yaş sürgün ağırlığı değerleri.

Table 9. Values of wetaverageweight of varieties.

\begin{tabular}{ccccc} 
Çeşitler & Ortalamalar & & & \\
\hline Gözdem & 0,04 & $\mathrm{a}$ & & \\
\hline Burak & 0,03 & & $\mathrm{~b}$ & \\
\hline Batem Efe & 0,02 & & & $\mathrm{c}$ \\
\hline LSD $(0,05): 0,01$ & & &
\end{tabular}

Çeşitler içerisinde en yüksek yaş sürgün ağırlığı Gözdem çeşidinde, en düşük yaş sürgün ağırllğı ise Batem Efe çeşidinde görülmüştür. Masmoudi ve ark. (2001) bildirilerinde, makarnalık buğdayın tuza hassas (S1) hattı ile tuza dayanıklı (R1) hattını kullanarak kısa dönem (3gün) $\mathrm{NaCl}$ (kontrol ve $200 \mathrm{mM}$ ) uygulamışlardır. Uygulama sonunda tuzun her iki genotipi de etkilediğini, yaş-kuru kök ve sap ağırlığını azalttığını ve bu azalma oranının S1 bitkilerinde daha fazla olduğunu bildirmişlerdir.

Eker ve ark. (2006) on dokuz misır (Zeamays) çeşidine büyümelerinin erken döneminde $250 \mathrm{mMNaCl}$ uygulama yapılan bir çalışmada, 17 gün süren yetiştirme periyodu sonrası bitkilerde meydana gelen toksisite belirtileri çeşitler arasında önemli derecede değişmiş̧tir. Fide büyümesindeki azalmalar, kök uzunluğundaki azalmalardan fazla bulunmuştur. 
Çizelge 10. Tuz konsantrasyonları ortalamalarının yaş sürgün ağırlığı üzerine etkisi.

Table 10. Theeffect of salt concentrations on thewet-exileweight of averages.

\begin{tabular}{|c|c|c|c|}
\hline T.K. (ppm) & Ortalamalar & & \\
\hline Saf su & 0,05 & $\mathrm{a}$ & \\
\hline 1500 & 0,04 & & $\mathrm{~b}$ \\
\hline 3000 & 0,04 & & $\mathrm{~b}$ \\
\hline 5000 & 0,02 & & \\
\hline 10000 & 0,02 & & \\
\hline 7500 & 0,02 & & \\
\hline 15000 & 0,01 & & \\
\hline
\end{tabular}

Tuz konsantrasyonları içerisinde en yüksek yaş sürgün ağırlığı saf su, en düşük ortalama ise 15000 ppm'lik konsantrasyonda görülmüştür. Sürgün oluşumu için tuz konsantrasyonundaki artış sürgün oluşumunu azaltmıştır. Çimlenen tohumun sürgün oluşturması tuz konsantrasyonuna bağlı olarak azalma göstermiştir. Tuz konsantrasyonunun fazla olması ortamın osmotik basıncından dolayı tohumun suyu almasını engelleyerek sürgün oluşumunda azalma göstermiştir.

\section{Yaş Kök Ağırlı̆̆ı (gr/bitki)}

Tüm varyasyon kaynaklarına LSD testi uygulanmış ve sonuçlar ayrı ayrı çizelgeler halinde verilmiştir. Yapılan analiz sonuçlarına göre yaş kök ağırlı̆̆ı ortalamalarının sıcaklıklar arasında istatistiki açıdan \%5’lik düzeyde önemli çıktığı görülürken; çeşit ve tuz konsantrasyonu \%1 seviyesinde önemli bulunmuştur.

Çizelge 11. Sıcaklık ortalamalarının yaş kök ağırlığı üzerine etkisi.

Table 11. Theeffect of temperatureaverages on wetrootweight.

\begin{tabular}{|c|c|c|}
\hline Sicaklık $\left({ }^{\circ} \mathrm{C}\right)$ & Ortalamalar & \\
\hline 24 & 0,06 & $\mathrm{a}$ \\
\hline 32 & 0,04 & $\mathrm{~b}$ \\
\hline 28 & 0,04 & $\mathrm{~b}$ \\
\hline
\end{tabular}

Yaş kök ağırlığı ortalamalarında en yüksek değer $24{ }^{\circ} \mathrm{C}$ 'de elde edilmiştir. En düşük ağırlık ortalaması ise 28 ve $32^{\circ} \mathrm{C}^{\prime}$ de ortaya çıkmıştır.

Sava (1995) bildirisinde, bazı yem bitkilerinin kök ağırlığı ortalamasının uygun koşulunun $20^{\circ} \mathrm{C}$ olduğunu ileri sürmüştür. Yıldız ve ark. (2007) bildirilerinde, mısır bitkisinin $25^{\circ} \mathrm{C}$ sıcaklıkta çimlendirme çalışmalarını yürüterek, çimlenen fidelerin yavaş geliştiklerini ileri sürmüşlerdir.

Çizelge 12. Çeşit ortalamalarının yaş kök ağırlığı değerleri.

Table 12. Values of wetrootweight of varietiesaverage.

\begin{tabular}{cccc}
\hline Çeşitler & Ortalamalar & & \\
\hline Gözdem & 0,05 & $\mathrm{a}$ & \\
\hline Batem Efe & 0,05 & $\mathrm{a}$ & \\
\hline Burak & 0,04 & & $\mathrm{~b}$ \\
\hline LSD $(0,05): 0,01$ & & &
\end{tabular}

Çeşitler arasında yapılan analiz sonuçlarına göre istatistiki açıdan \%1'lik düzeyde fark görülmüştür. Bu fark sonucunda en fazla yaş kök ağırlığı ortalaması Gözdem ve Batem Efe; en düşük ortalama ise Burak çeşidinde saptanmıştır. Çimlenen tohumların kök yapılarının gelişim göstermesi tohum iriliği ile doğru orantılı olarak büyükten küçüğe olarak ortaya çıkmıştır. Çeşitlerden tane iriliği en yüksek olan Gözdem çeşididir ki zaten en yüksek kök ağırlığı ortalamasını da bu çeşidi göstermiş̧tir. 
Singh ve ark. (1975) arpada yaptıkları bir çalışmada; iri tohumluğun ilk gelişme devresini hızlandırdığını, bitkide kardeş sayısı ve birim alan tane verimini artırdığını, ayrıca tohum iriliği ile birim alan tane verimi arasında olumlu bir ilişkinin bulunduğunu belirtmişlerdir.

Main ve ark. (1994) iri tohumların çevresel stres şartlarından özellikle kurak şartlarda avantaj sağladığını belirtmişlerdir. Khan ve ark. (2000) Pakistanda kuru şartlarda yaptıkları buğday çalışmasında iri tohumların metrekaredeki bitki sayısını ve verimi artırdığını bildirmişlerdir.

13. Tuz konsantrasyonları ortalamalarının yaş kök ağırlığı üzerine etkisi.

Table 13. Theeffect of salt concentrations on thewetrootweight of averages.

\begin{tabular}{|c|c|c|c|c|c|}
\hline T.K. (ppm) & Ortalamalar & & & & \\
\hline Saf su & 0,07 & $\mathrm{a}$ & & & \\
\hline 3000 & 0,06 & $\mathrm{a}$ & $\mathrm{b}$ & & \\
\hline 1500 & 0,06 & $\mathrm{a}$ & $\mathrm{b}$ & & \\
\hline 5000 & 0,05 & & $\mathrm{~b}$ & $\mathrm{c}$ & \\
\hline 7500 & 0,04 & & & $\mathrm{c}$ & d \\
\hline 10000 & 0,03 & & & & $\mathrm{~d}$ \\
\hline 15000 & 0,02 & & & & d \\
\hline
\end{tabular}

İstatistiki analiz sonuçlarına göre tuz konsantrasyonlarının yaş kök ağırlı̆ğ ortalamaları arasında \%1'lik düzeyde fark bulunmuştur. En fazla yaş kök ağırlı̆ğ ortalamasını saf su konsantrasyonu göstermiştir. En düşük ortalama sonucu 10000ve15000 ppm'lik konsantrasyonda elde edilmiştir.

\section{Sürgün Kuru Ağırlığı (gr)}

Sürgün kuru ağırlı̆̆ına ait ortalama değerler, çizelgeler halinde aşağıdaki gibi verilmiş̧tir. Varyasyon kaynaklarına ait en yüksek ve düşük değerler belirlenmiş̧ir.

Çizelge 14. Sıcaklık ortalamalarının sürgün kuru ağırlığına etkisi.

Table 14. Theeffect of temperatureaverages on exiledryweight.

\begin{tabular}{cc} 
Sicaklık $\left({ }^{\circ} \mathrm{C}\right)$ & Ortalamalar \\
\hline 28 & 0,04 \\
\hline 24 & 0,03 \\
\hline 32 & 0,03
\end{tabular}

Sürgün kuru ağırlığı özelliğinin ortalama değerleri ne bakıldığında $28^{\circ} \mathrm{C}$ sıcaklıkta $(0,04$ gr $)$ en yüksek oran ortaya çıkmaktadır. $24^{\circ} \mathrm{C}(0,03$ gr $)$ ve $32^{\circ} \mathrm{C}$ 'de $(0,03$ gr $)$ düşük ortalamalar elde edilmiştir.

Çizelge 15. Çeşitlerin sürgün kuru ağırlık ortalama değerleri.

Table 15. Dryweightaveragevalues of varieties.

\begin{tabular}{cc} 
Çeşit & Ortalamalar \\
\hline Gözdem & 0,11 \\
\hline Burak & 0,08 \\
\hline Batem Efe & 0,05
\end{tabular}

Gözdem çeşidinin sürgün kuru ağırlığ 0,11 gr olurken, Burak 0,08 gr ve Batem Efe 0,05 gr ile daha düşük ortalamalara sahiptir. 
Çizelge 16. Tuz konsantrasyonları ortalamalarının sürgün kuru ağırlığı üzerine etkisi.

Table 16. Theeffect of salt concentrations on thedrydryweight of theaverages.

\begin{tabular}{cc}
\hline T.K. (ppm) & Ortalamalar \\
\hline Saf su & 0,13 \\
\hline 5000 & 0,10 \\
\hline 1500 & 0,09 \\
\hline 3000 & 0,08 \\
\hline 7500 & 0,06 \\
\hline 10000 & 0,06 \\
\hline 15000 & 0,05
\end{tabular}

Tuz konsantrasyonları arasındaki en yüksek ortalamayı saf su konsantrasyonu gösterirken, en düşük ortalama değer 15000 ppm'lik konsantrasyonda görülmüştür.

Saptanan sonuçlar doğrultusunda, Saboora ve Kiarostami (2006) tarafindan buğdayda; Jamil ve Rha (2007) tarafından pirinçte; Bakht ve ark. (2006), Almodares ve ark. (2007) ve Nawaz ve ark. (2010) tarafindan, sorgumda elde edilen değerlerle benzerlik göstermektedir.

\section{Kök Kuru Ağırlığı (gr)}

Kök kuru ağırlığına ait ortalama değerler, varyasyon kaynaklarına göre çizelgeler halinde aşağıdaki gibi verilmiştir.

Çizelge 17. Sıcaklık ortalamalarının kök kuru ağırlığına etkisi.

Table 17. Theeffect of temperatureaverage on rootdryweight.

\begin{tabular}{cc}
\hline Sicaklik $\left({ }^{\circ} \mathrm{C}\right)$ & Ortalamalar \\
\hline 32 & 0,05 \\
\hline 28 & 0,04 \\
\hline 24 & 0,02
\end{tabular}

Kök kuru ağırlığı ortalama sonuçları gösteriyor ki $32{ }^{\circ} \mathrm{C}$ sıcaklıkta en yüksek değer saptanırken $(0,05$ gr) 28 $\left(0,04\right.$ gr) ve $24{ }^{\circ} \mathrm{C}$ 'de $(0,02$ gr) daha düşük oranlar bulunmuştur. Kök gelişimi için düşük sıcaklık yerine yüksek sicaklık değerleri daha iyi bir sonuç ortaya çıkarmaktadır.

Çizelge 18. Çeşit ortalamalarının kök kuru ağırlık değerleri.

Table 18. Therootdryweightvalues of thevarietiesaverages.

\begin{tabular}{cc}
\hline Çeşit & Ortalamalar \\
\hline Gözdem & 0,12 \\
\hline Batem Efe & 0,07 \\
\hline Burak & 0,07
\end{tabular}

Gözdem çeşidinin kök kuru ağırlık değeri $(0,12$ gr) diğer çeşitlerden daha yüksek orana sahip olduğu görülmüştür. Batem Efe ve Burak çeşitlerinin (0,07 gr) aynı ortalama değere sahip olduğu saptanmıştır.

Nawaz ve ark. (2010) sorgumda elde ettikleri değerlerin tuzun konsantrasyon artışına bağlı olarak erken fide dönemi özellikleri (kök ve sürgün uzunluğu, kök ve sürgün kuru ağırlığı) değerlerinde azalmalar meydana geldiğini bildirmişlerdir. 
Table 19. Theeffect of salt concentrations on rootdryweight of averages.

\begin{tabular}{cc}
\hline T.K. (ppm) & Ortalamalar \\
\hline Saf su & 0,12 \\
\hline 1500 & 0,09 \\
\hline 3000 & 0,11 \\
\hline 5000 & 0,10 \\
\hline 7500 & 0,07 \\
\hline 10000 & 0,08 \\
\hline 15000 & 0,05
\end{tabular}

Tuz konsantrasyonları arasındaki istatistiki bakımdan farklılık olmamasına karşılık en yüksek kök kuru ağırlığı ortalama saf su konsantrasyonunda ortaya çıkarken, en düşük ortalama 15000 ppm'lik konsantrasyonda görülmüştür. Kök kuru ağırlığı için en yüksek ortalama $32{ }^{\circ} \mathrm{C}$ sıcaklıkta, Gözdem çeşidi ve saf su konsantrasyonu olduğu elde edilmiştir.

Bohnert ve ark. (1995); Warner ve Finkelstein (1995); Al-Karaki (2001) tarafindan kuru kök-sürgün ağırlıkları ile tuz konsantrasyonları arasındaki ilişki incelendiğinde, diğer erken fide dönemi parametrelerinde olduğu gibi her bir farklı tuz konsantrasyonu artışıyla söz konusu değerlerin azaldığı görülmektedir. Tuz yoğunluğundaki artış kök gelişimini geciktirmiş, uzamasını azaltmıştır. Tuzlu ortamlarda artan konsantrasyonlara bağlı olarak kök ve sürgün kuru ağılık içeriğinin azaldığını gösteren sonuçlar, ortamın yüksek osmotik basıncından dolayı köklerin yeterince su alamamasıyla açıklanabilir.

\section{Sonuc}

Akdeniz sahil kuşağı boyunca silajlık mısır üretimi için kullanılan 3 farklı çeşidin farklı sıcaklık ve tuz konsantrasyonlarında çimlenme dönemi ve fide gelişimi sürecindeki gelişimlerini ortaya koymak amacıyla bu çalışma planlanmıştır. Çalışma sonucunda çimlenme oranı açısından en yüksek değer $\% 81,27$ ile $24{ }^{\circ} \mathrm{C}$ 'de; en düşük değer ise $32{ }^{\circ} \mathrm{C}$ 'den elde edilmiştir. Çeşitler bakımından çimlenme oranlarını incelediğimizde en yüksek değerin Gözdem $(\% 73,17)$ ve Batem Efe $(\% 69.05)$ çeşidinden; en düşük ortalamanın ise Burak (\%52.54) çeşidinden sağlandığı görülmektedir. Ele alınan tuz konsantrasyonları açısından en yüksek çimlenme oranı saf su ortamında elde edilirken bunu 3000 ppm'lik konsantrasyon takip etmiştir. Çimlenme oranı ortalamalarına ait üçlü interaksiyon değerlerine göre sıcak bölgelerde ve daha yüksek tuz konsantrasyonuna ait yerlerde Gözdem; daha düşük sicaklık ve daha az tuz konsantrasyonuna ait yerlerde ise Batem Efe ve yine Gözdem çeşitlerinin daha iyi çimlenme oranı yakaladığı saptanmıştır.

Araştırma sonuçları gösteriyor ki çalışmada kullanılan tuz konsantrasyonlarından en yüksek iki tuz konsantrasyonu olan 20000 ve 25000 ppm ortamında çeşitlerde çimlenme olmadığ gözlemlenmiştir. Tuz konsantrasyonunun artması tohumda suyun geçişinin engellenmesine ve tohumların çimlenememesine sebep olmaktadır.

Akdeniz sahil kuşağı boyunca çimlenme ve fide gelişimini en yüksek oranda Gözdem çeşidi, $24^{\circ} \mathrm{C}$ sıcaklıkta ve 5000 ppm' lik tuz konsantrasyonuna kadar olan ortamlarda göstermiştir. İyi bir bitki gelişimi için önemli olan yaş ağırlık ve tohum iriliğini de karşılayabilecek olmasından dolayı ele alınan üç çeşit içerisinden Gözdem çeşidinin tavsiye edilebileceği belirlenmiştir. Batem Efe çeşidinin çimlenme oranı açısından Gözdem çeşidinden sonra ikinci sırada değerler vermesine karşılık ele alınan diğer özellikler birlikte değerlendirildiğinde Burak çeşidinin Gözdem çeşidini takip ettiği anlaşılmışıtır. Bunun yanında düşük tuz konsantrasyonlarında ve düşük sıcaklıklarda Batem Efe; yüksek tuz konsantrasyonunda ve yüksek sıcaklıklarda ise Gözdem çeşidi kullanılabilinir.

Bölgede mısır yetiştiriciliği hem sıcaklık değerlerinin hem de tuz konsantrasyonlarının büyüme sezonu içerisindeki süreç bakımından daha geniş alan kaplaması özellikle sıcaklık*çeşit*tuz konsantrasyonu interaksiyonunun etkinliğini arttırmıştır. Sicaklık derecesinin $24^{\circ} \mathrm{C}$ olduğu ve tuz konsantrasyonun toprakta 5000 ppm (EC değeri: $8,83 \mathrm{mS} / \mathrm{cm}$ ) konsantrasyonuna kadar olduğu alanlarda iyi bir mısır yetiştiriciliğinin yapılabileceği; bu konsantrasyondan daha yüksek tuz konsantrasyonu olan topraklarda ise çimlenme ve fide gelişimi açısından sıkıntıların oluşacağı saptanmıştır. 


\section{Kaynaklar/References}

Açıkgöz, E., 2001. Yem Bitkileri. Uludağ Üniversitesi Güçlendirme Vakfı Yayın NO:182.

Ahmad, J., Bano, M., 1992. Theeffect of sodiumchloride on thephysiology of cotyledonsandmobilization of reservedfood in Cicerarietinum, Pak. J.Bot., 24, 40-48.

Al-Karaki, GN., 2001. Germination, sodium, andpotassiumconcentrations of barleyseeds as influencedbysalinity. Journal of PlantNutrition 24: $511-512$

Almodares, A., Hadi, Mr., Dosti, B., 2007. Effects of salt stress on germinationpercentageandseedlinggrowth in sweetsorghumcultivars. JournalofBiologicalSciences 7: 1492-1495.

Avcı, M., Güler, M., Pala, M., Karaca, M. ve Eyüboğlu, H., 1987. Yetiștirme Tekniği Paketi Öğelerinin Orta Anadolu Bölgesi Kurak Koșullarında Buğday Verimine Etkileri, Türkiye Tahıl Sempozyumu, 1987, Bursa.

Bakht, J., Basir, A., Shafi, M., Khan, M.J., 2006. Effect of variouslevels of salinity on sorghum at earlyseedlingstage in solutionculture. SarhadJournal of Agriculture 22: 17-21

Bohnert, HJ., Nelson, DE., Jensen, RG., 1995. Adaptationstoenviromentalstresses. Plant Cell 7: 1099-1111.

Botella, M.A., Rosado, A., Bressan, R.A. ve Hasegawa, P.M., 2005. PlantAdaptiveResponsestoSalinityStress, PlantAbioticStress, Blackwell Publishing Ltd., 270p.

Bozcuk, S., 1991. Bazı kültür bitkilerinde tuzluluğun çimlenme üzerine etkisi ve tuz toleransı sınırlarının saptanması, Doağ-Tr. J. Biol., 15, 144-151.

Dajic, Z., 2006. Salt Stress, PhysiologyandMolecularBiology of StressTolerance in Plants, ISBN-13 978-1-4020-4224-9, Dordrecht, TheNetherlands, 345p.

De Villiers, A.J., Van Rooyen, M.W., Theron G.K., Van De Venter, H.A., 1994. Germination of threeNamaqualandpioneerspecies, as influencedbysalinity, temperatureandlight, SeedSci. Technol., 22,427-433.

Eker, S., Cömertpay, G., Konuskan, O., Ulger, A.C., Ozturk, L. and Cakmak, İ., 2006. Effect Of SalinityStress on DryMatterProductionandİonAccumulation in HybridMaizeVarieties. Turkish J. Agric. For., 30(5) 365-373.

FAO, Eylül 2016, FAOSTAT | C FAO StatisticsDivision 2016 | 22 September 2016.

Gençkan, S., 1983. Yem Bitkileri Tarımı, Ege Üniversitesi, Bornova İzmir, 9.

Gomes Filho, E., Sodek L., 1988. Effect of salinity on ribonucleaseactivity of Vignaunguiculatacotyledonsduringgermination, J. PlantPhysiol., $132,307-311$.

Hartmann, H.T., Kester, D.E. andDavies, F.T., 1990. PlantPropagation. Principles of PropagationbySeed. 647 p.

Hong, C-Y., Chao, Y-Y., Yang, M-Y., Cho, S-C. andKao, C.H., 2009. Na+ But Not Cl- or OsmoticStress is Involved in NaClInducedExpression of GlutathioneReductase in Roots of Rice Seedlings, Journal of PlantPhysiology, 166, 1598-1606.

Jamil, M. and Rha, E.S., 2007, Gibberellicacid (GA3) enhanceseedwateruptake, germinationandearlyseedlinggrowth in sugarbeetunder salt stress, Pakistan Journal of BiologicalSciences, 10(4): 654-658.

Kaçar, B., 1989. “Bitki Fizyolojisi”, Ankara Üniversitesi Ziraat Fakültesi, Yayın No: 1153, Ders Kitabı sf:323, ANKARA.

Khan, M.A., Rizvi, Y., 1994. Effect of salinity, temperatureandgrowthregulators on thegerminationandearlyseedlinggrowth of Atriplexgriffithii var. Stocksii, Can. J. Bot., 72, 475-479.

Khan M.A., Ungar I.A., 1997. Effects of light, salinityandthermoperiod on theseedgermination of halophytes, Can. J. Bot., 75, 835-841.

Lawlor, D.W.,2000, Limitation of photosynthesis in waterstressedleaves, stomata vs. metabolismandthe role of ATP. Ann. Bot. (89) 1-15pp.

Main, M.A.R., andNafziger, E.D., 1994 Seed size andwaterpotantialeffects on germinationandseedlinggrowth of winterwheat. CropSci., 36: $169-171$

Masmoudi, K., Brini, F., Hassairi. AndEllouz,R., 2001. IsolationandCharacterization of a DifferentiallyExpressedSeqenceTagfromTriticum Durum Salt-StressedRoots. PlantPhysiology, Biochemistry, 39: 971-979.

Munns, R., 2002. Salinity, GrowthandPhytohormones, Salinity: Environment-Plants-Molecules, PublishedbyKluwerAcademicPublishers, ISBN 1-4020-0492-3, Dordrecht, TheNetherlands, 522p.

Nawaz, K., Talat, A., Hussain, K., Majeed, A., 2010. Induction of salt tolerance in twocultivars of sorghum (SorghumbicolorL.) byexogenousapplication of proline at seedlingstage. World AppliedSciencesJournal 10: 93-99.

Patane, C., Saita, A. and Sortino,O.,2013, Comparativeeffects of salt andwaterstress on seedgerminationandearlyembryogrowth in twocultivars of sweetsorghum. J. Agron. CropSci. (199) 30-37pp.

Poljakoff-Mayber, A., Somers, G.F., Werker, E., Gallagher, J.L., 1994. Seeds of Koteletzkyavirginica(Malvaceae): theirstructure, germinationand salt tolarence, Am. J. Bot., 81, 54-59.

Saboora, A., Kiarostami, K., 2006 Salinity $(\mathrm{NaCl})$ tolerance of wheatgenotypes at germinationandearlyseedlinggrowth. Pakistan Journal of BiologicalScience9: 2009-2021.

Sarıcan, C., Çete, N. 1998, Silajlık Yem Bitkileri Üretimi ve Silaj Yapımı Amerikan Tahıl Konseyi Yayını. İzmir.

Sava. B., 1995 Farklı Sıcaklık Derecelerinin Bazı Tek Yıllık Baklagil Yem Bitkilerinin Çimlenmeleri Üzerine Etkileri. 
Singh A.K., Tripathi I.D. andChowdhury R.K., 1975. Effect of Seed Size on SeedlingGrowthandMaturePlantCharactes in Barley (HordeumvulgareL.). FieldCropAbst. 29 (10) 7661.

Warner J.E., Finkelstein R.R., 1995. ArabidopsismutantswithreducedresponsetoNaClandosmoticstress. PhysiologiaPlantarum 93: 659-666.

Yıldız M., Cenkci S., Terzi H., Konuk M., 2007. Effects of salinity on germinationandsomegrowthparameters in threecultivars of Zeamays L., Afyon Kocatepe UniversityJournal of Science, InPress.

Yupsanis, T., Moustakas, M., Domiandou, K., 1994. Protein phosphorylation- dephosphorylation in alfalfaseedsgerminatingunder salt stres, J. PlantPhsysiol., 143, 234-240. 